\title{
INTERFACE ENTRE GEODIVERSIDADE E BIODIVERSIDADE NA RESERVA BIOLÓGICA DO IBIRAPUITÃ, RIO GRANDE DO SUL
}

\author{
Tanice Cristina Kormann \\ Universidade Federal do Rio Grande do Sul, Instituto de Geociências, Porto Alegre, RS, Brasil \\ tanice.kormann@gmail.com \\ Luís Eduardo de Souza Robaina \\ Universidade Federal de Santa Maria, Departamento de Geociências, Santa Maria, RS, Brasil \\ lesrobaina@yahoo.com.br
}

\begin{abstract}
RESUMO
O presente trabalho tem por objetivo caracterizar a geodiversidade da Reserva Biológica do Ibirapuitã (REBIO do Ibirapuitã). Situada no município de Alegrete, região sudoeste do Rio Grande do Sul, a área foi instituída por decreto estadual em 1976. Trata-se de uma das poucas Unidades de Conservação de proteção integral situadas no bioma Pampa, sendo este um dos biomas que possuem menor percentual de áreas protegidas. As informações disponíveis a respeito desta unidade de conservação são escassas, sendo que a maior parte se refere a fauna e flora local. Desta forma, o principal objetivo deste trabalho consiste na geração e divulgação de conhecimento a respeito da geodiversidade desta área. O uso de técnicas de geoprocessamento permitiu a integração de informações básicas para a caracterização da área com os dados coletados em campo. Como resultado, o trabalho permitiu identificar formas e feições do relevo, evidenciando estreita relação dos elementos abióticos com os elementos bióticos. Neste sentido, o trabalho contribui com a geração de informações indispensáveis para a elaboração de instrumentos de gestão desta unidade de conservação, bem como para a divulgação do conhecimento científico.
\end{abstract}

Palavras-chave: Patrimônio natural. Áreas protegidas. Unidade de conservação. REBIO do lbirapuitã. Pampa.

\section{INTERFACE BETWEN GEODIVERSITY AND BIODIVERSITY IN THE IBIRAPUITÃ BIOLOGICAL RESERVE, RIO GRANDE DO SUL}

\begin{abstract}
This work aims to characterize the geodiversity of the lbirapuitã Biological Reserve (REBIO do Ibirapuitã). Located in the municipality of Alegrete, in the Southwest region of Rio Grande do Sul, the area was established by state decree in 1976. It is one of the few fully protected Conservation Units located in the Pampa biome, which is one of the biomes with the lowest percentage of protected areas. The information available regarding this conservation unit is scarce, with most of it referring to the local fauna and flora. Thus, the main objective of this work is to generate and disseminate knowledge about the geodiversity of this area. The use of geoprocessing techniques to integrate basic information to the area with the data collected in the field. As a result, the work made it possible to identify forms and features of the relief, showing a close relationship between abiotic elements and biotic elements. In this sense, the work contributes to the generation of essential information for the development of management instruments for this conservation unit, as well as for the dissemination of scientific knowledge.
\end{abstract}

Keywords: Natural heritage. Protected Area. Conservation unit. REBIO do Ibirapuitã. Pampa.

\section{INTRODUÇÃO}

A instituição de áreas protegidas visando à conservação das características naturais é um dos principais instrumentos da Política Nacional do Meio Ambiente (PNMA) e uma das estratégias do Poder Público para assegurar a manutenção da qualidade ambiental (BENSUSAN, 2006). Sendo um dos instrumentos de efetivação da PNMA, o Sistema Nacional de Unidades de Conservação (SNUC) é responsável por articular os mecanismos de regulamentação das categorias federal, estadual e municipal dos espaços de proteção ambiental (BRASIL, 2000). As tipologias de Unidades de

$\begin{array}{lllll}\text { Caminhos de Geografia } \quad \text { Uberlândia-MG } & \text { v. 22, n. 79 } & \text { Fev/2021 } & \text { p. 112-126 Página } 112\end{array}$


Conservação propostas pelo SNUC estão organizadas em categorias de acordo com os objetivos e finalidades de uso da área protegida; sendo divididas em unidades de Proteção Integral e de Uso Sustentável (BRASIL, 2000). O primeiro grupo se propõe a garantir a não interferência humana direta, portanto o modelo de gestão do território é mais restritivo se comparado às áreas protegidas inseridas no segundo grupo.

As Reservas Biológicas são unidades de conservação inseridas na categoria de Proteção Integral, que tem por objetivo preservar a biota juntamente com os atributos naturais integrantes do seu território (BRASIL, 2000). As atividades permitidas nesta tipologia de unidade de conservação são apenas aquelas ligadas à pesquisa científica e educação ambiental (RIO GRANDE DO SUL, 1998). Nesta categoria de proteção são inseridas áreas em que a riqueza de elementos da biodiversidade justifica a necessidade de preservação de espécies da fauna e flora in situ ou que exijam a adoção de medidas de restrição de acesso da população a fim de assegurar sua manutenção.

O Plano de Manejo é um documento técnico obrigatório para orientar a gestão de unidades de conservação. Estabelecido no Art. 27 da Lei n 9.985 de 2000, que institui o Sistema Nacional de Unidades de Conservação da Natureza, indica tratar-se de um instrumento de gestão territorial que resulta da integração de informações (BRASIL, 2000). No Brasil, ainda costuma ser recorrente o fato de que os elementos abióticos existentes nas áreas protegidas só são conhecidos na fase de elaboração do Plano de Manejo. A este respeito, Cristo (2013) considera que, no país, os aspectos geomorfológicos não são enfatizados na criação das UCs, o que é explicado pelo fato de que o paradigma mundial que norteou a criação da maior parte das áreas protegidas durante a segunda metade do século XX foi intrinsecamente ligado a biodiversidade (BRILHA, 2005).

Contudo, há que se ressaltar que a biodiversidade que se pretende proteger está sustentada por uma geodiversidade que é suporte material para a manutenção dos sistemas ecológicos (BRILHA, 2005; REYNARD e BRILHA, 2018). O conceito de geodiversidade busca englobar "la diversidad geológica de un territorio, entendida como la variedad de rasgos geológicos presentes en un lugar, identificados tras considerar su frecuencia, distribución y cómo éstos ilustran la evolución geológica del mismo." (CARCAVILLA; DURÁN; LÓPEZ-MARTÍNEZ, 2008, p. 1299). De forma simplificada, a geodiversidade seria a equivalente abiótica para a biodiversidade (CROFTS e GORDON, 2014; REYNARD e BRILHA, 2018).

Nas últimas décadas vem crescendo o número de pesquisas tentando chamar a atenção para a importância de se considerar os elementos naturais por meio de uma perspectiva mais abrangente, considerando as interrelações e os processos como chave para efetiva proteção da natureza presente em unidades de conservação. Tal perspectiva evidencia a necessidade de considerar o componente abiótico como preponderante para melhor compreender a dinâmica natural dos territórios, o que se mostra fundamental para a gestão de áreas ambientalmente protegidas (CRISTO, 2013).

\section{ÁREA DE ESTUDO}

A área de estudo pertence à mesorregião da Campanha Gaúcha, caracterizada como Domínio das Coxilhas Subtropicais com Pradarias Mistas (AB'SABER, 1970). Está inserida no bioma Pampa onde predominam as atividades de pecuária extensiva e cultivo de arroz e de soja. Situado na porção sul do Rio Grande do Sul, este bioma ocorre também no Uruguai e Argentina. Nos últimos anos vem sendo intensamente utilizado para a expansão do cultivo da soja no estado. Pesquisas indicam que "De 2000 a 2015 a área plantada com soja no RS aumentou 73,7\% principalmente na metade Sul do Estado. No bioma Pampa a área plantada de soja aumentou 188,5\% nesse período." (KUPLICH; CAPOANE; COSTA, 2018, p. 83). Apesar da crescente pressão exercida sob o bioma, cerca de $2,6 \%$ de sua área é atualmente protegida por unidades de conservação, configurando o menor percentual nacional de proteção (CHOMENKO e BENCKE, 2016; FONTANA e REED, 2019).

Uma das poucas unidades de conservação na categoria de Proteção Integral a resguardar remanescentes do bioma Pampa é a REBIO do Ibirapuitã. Instituída pelo Decreto Estadual $\mathrm{n}^{\circ}$ 24.622/1976, a área destina-se "à preservação de espécies animais e vegetais ocorrentes na fronteira oeste do Estado, bem como à realização de estudos e pesquisas objetivando a manutenção da integridade dos ecossistemas do território estadual" (RIO GRANDE DO SUL, 1976).

A REBIO do Ibirapuitã se insere no contexto de criação de UCs sob o paradigma da proteção da biodiversidade. A categoria de proteção evidencia o enfoque na preservação dos elementos bióticos, 
conforme destacado na maior parte dos documentos institucionais existentes até então, o que pode ser evidenciado no trecho a seguir:

Com relação à fauna terrestre, a Reserva Biológica do Ibirapuitã desempenha um importante papel na conservação da biodiversidade, pois mantém, apesar de suas dimensões reduzidas, numerosos microambientes que são ativamente ocupados pela fauna de pequenos vertebrados, sobretudo junto aos afloramentos rochosos, com destaque para a fauna de répteis (SEMA, 2001, p. 35).

A REBIO do Ibirapuitã está situada na margem direita do rio que lhe empresta o nome, distante cerca de $15 \mathrm{~km}$ da sede do município de Alegrete e cerca de $5 \mathrm{~km}$ de outra unidade de conservação maior e mais conhecida, a Área de Proteção Ambiental do Ibirapuitã (APA do Ibirapuitã), conforme Figura 1.

Figura 1 - Localização da REBIO do Ibirapuitã em relação a área urbana do município de Alegrete e a APA do lbirapuitã.

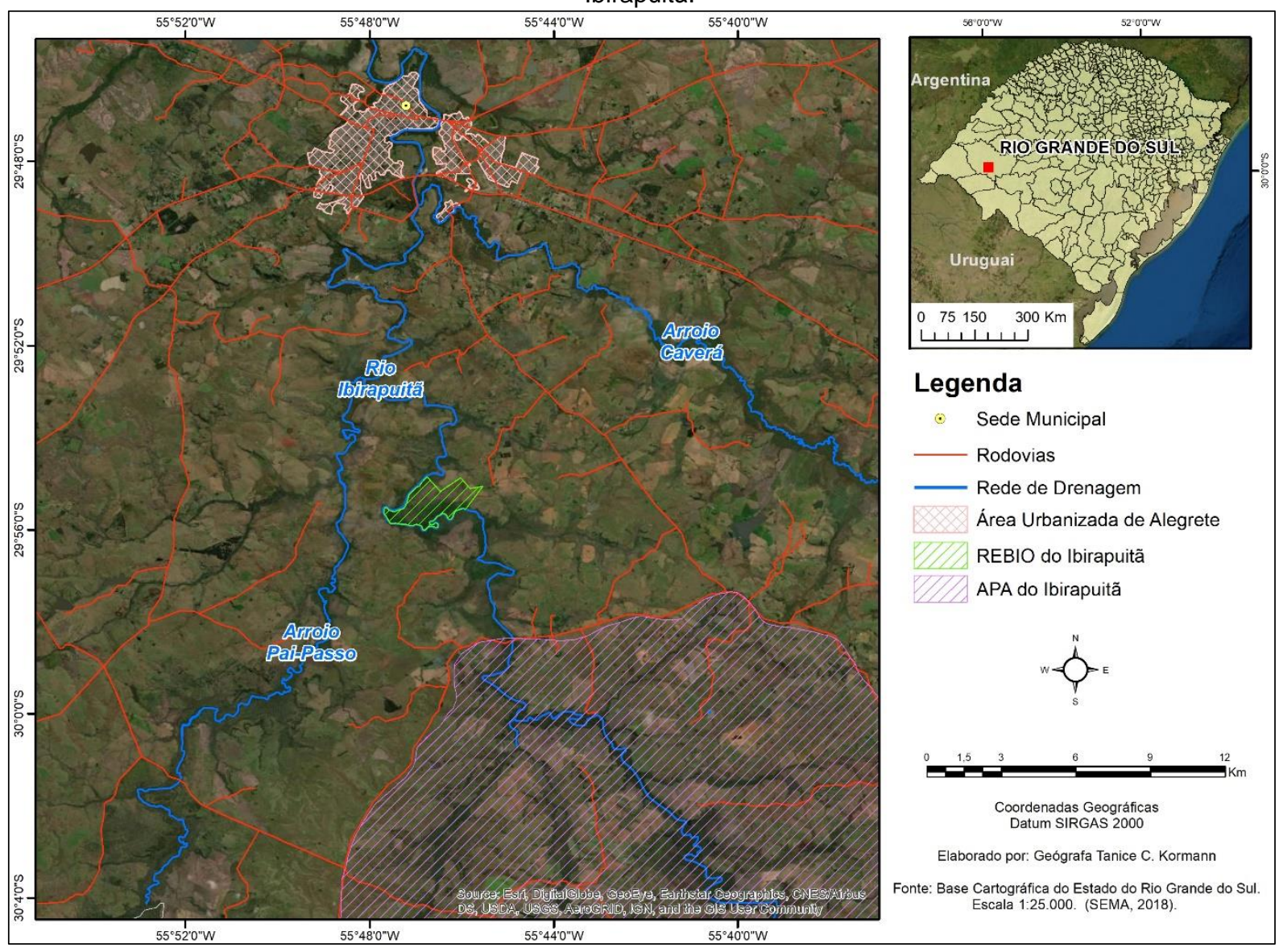

Fonte: Elaborado pelos autores.

A fim de estabelecer uma comparação e dirimir possíveis confusões, a REBIO do lbirapuitã possui 351,42 ha enquanto a APA do lbirapuitã abrange 316.790 ha. Para além da significativa diferença de tamanho, as duas unidades de conservação são geridas por diferentes esferas públicas de gestão ambiental. A REBIO do Ibirapuitã integra o Sistema Estadual de Unidades de Conservação (SEUC) enquanto a APA do Ibirapuitã é vinculada ao ICMBio, órgão do sistema federal. No que se refere ao grau de efetivação também há diferença entre as duas unidades conservação. A REBIO do lbirapuitã ainda não conta com Plano de Manejo e vem tentando criar seu Conselho Gestor, ao contrário da APA do Ibirapuitã que possui Plano de Manejo e Conselho Gestor instituído e atuante.

Outro aspecto a ser mencionado é que apesar da disponibilidade de conhecimento sobre a biodiversidade da REBIO do Ibirapuitã são quase inexistentes as informações disponíveis sobre sua geodiversidade. Mesmo se tratando de uma área relativamente pequena, a área protegida apresenta paisagens e feições superficiais que ilustram processos representativos das características

$\begin{array}{lllll}\text { Caminhos de Geografia } & \text { Uberlândia-MG } & \text { v. 22, n. 79 } & \text { Fev/2021 } & \text { p. 112-126 Página } 114\end{array}$


geomorfológicas e geológicas sob as quais estão sustentadas as belezas cênicas do bioma Pampa. É a partir desta perspectiva que o presente trabalho se propõe a apresentar os principais elementos da geodiversidade da REBIO do Ibirapuitã, de forma a estabelecer interrelações com a biodiversidade que serviu de motivação inicial para a criação desta unidade de conservação.

\section{METODOLOGIA}

O trabalho utilizou a abordagem sistêmica como orientação metodológica. A pesquisa teve início com o levantamento de referencial teórico e material cartográfico buscando auxiliar na caracterização da área, primeiramente em escala regional. A base de dados em escala regional utilizada para a elaboração dos mapas é listada na sequência: a) Mapeamentos temáticos na escala 1:250.000 dos temas geomorfologia, geologia e vegetação disponibilizados pelo Instituto Brasileiro de Geografia e Estatística (IBGE, 2003a; IBGE, 2003b; IBGE, 2003c); b) Limites das Unidades de conservação, malha municipal, rede de drenagem, rodovias e altimetria disponibilizada pela Secretaria de Meio Ambiente e Infraestrutura do Estado do Rio Grande do Sul (SEMA, 2018) na escala 1:25.000.

Ao possibilitar uma série de análises, o geoprocessamento se destaca como ferramenta de aplicação multidisciplinar contribuindo para a obtenção, geração e apresentação de informações espaciais (SILVA e ZAIDAN, 2004). O uso de técnicas de geoprocessamento permitiu a integração de informações básicas referente à área de estudo. Foi utilizado o software Arc Gis 10.4.1 $₫$ da ESRI para o cruzamento das bases de dados geoespaciais de escala regional com as informações primárias. Para levantamento de dados em campo foi utilizado o Receptor Garmin Modelo GPSMAP 60CSx.

Foram realizadas duas saídas a campo, nos meses de março e maio de 2011, buscando coletar informações relativas à rede de drenagem bem como diferenciar o substrato litológico além das formas e feições do relevo que caracterizam a geodiversidade da REBIO do Ibirapuitã. Estas informações resultaram no perfil esquemático das feições superficiais e no mapa litológico. A análise em maior escala de detalhamento foi complementada por imagem de alta resolução do satélite WorldView de 7 de outubro de 2017 com resolução espacial de $0,7 \mathrm{~m}$ e resolução radiométrica de 8 bits (SEMA, 2019). Tal procedimento resultou no mapa ilustrativo dos processos da dinâmica fluvial contemplando a drenagem interna da UC, no mapa das fisionomias vegetais e no mapeamento de feições superficiais que compõe o mapa litológico.

A identificação de espécies da flora foi realizada a partir de consulta a estudos fitogeográficos realizados na região (ALVES, 2008; MARCHIORI e ALVES, 2010). Além destas pesquisas, os nomes científicos foram conferidos na base de dados do site Flora do Brasil (FLORA DO BRASIL, 2020).

\section{RESULTADOS E DISCUSSÕES}

O relevo da área é caracterizado pelo baixo gradiente altimétrico, com as menores altitudes nas porções mais próximas ao Rio lbirapuitã (cerca de $80 \mathrm{~m}$ ) e as maiores alcançando os $150 \mathrm{~m}$ nas porções centronorte da unidade de conservação. As formas predominantes são vertentes suavemente onduladas, com amplitudes entre $10 \mathrm{~m}$ e $20 \mathrm{~m}$ e declividades entre 2 e $5 \%$, denominadas de colinas. Essas traduzem os efeitos dos desgastes ocasionados pelo clima subtropical úmido (AB'SABER, 1970) em substrato formado por acamamento sub-horizontal com zonas de fraqueza associadas a fraturas.

Outra forma de relevo característica dessa região é a cornija, que corresponde a feição indicativa de porções mais resistentes do substrato rochoso, em geral associado a arenitos coesos. Se trata de afloramentos rochosos de arenito com maior concentração de sílica na posição de terço superior da encosta (Figura 2). As cornijas marcam a transição de uma porção de topo do relevo, onde ocorrem as rochas cristalinas, para a porção inferior com arenito menos coeso da Formação Botucatu.

Estas feições constituem uma ruptura na paisagem local, por vezes se assemelhando a muros de pedra em função da linearidade que assumem. Posicionadas no terço superior da encosta, são representadas pelos afloramentos rochosos que formam pequenas escarpas que constituem a principal quebra de declive nas formas de relevo presentes na REBIO do Ibirapuitã. As cornijas são entalhadas pelas drenagens de primeira ordem e por drenagens intermitentes que correspondem as principais características das drenagens presentes na unidade de conservação (Figura 3). 
Figura 2 - Aspecto linear da ocorrência das cornijas marcando uma condição de transição de relevo.

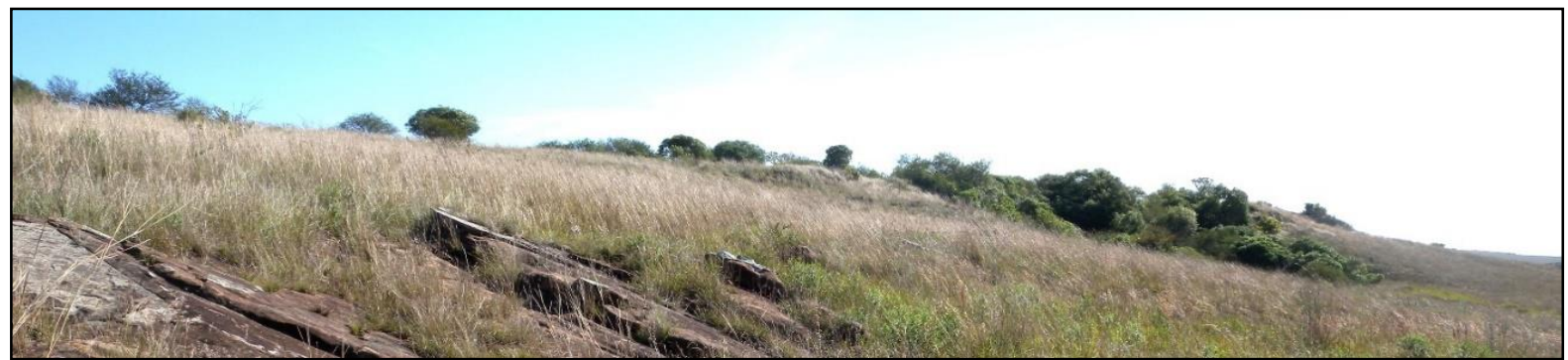

Fonte: Arquivo dos autores.

Figura 3 - Drenagem intermitente que alcança a cornija.

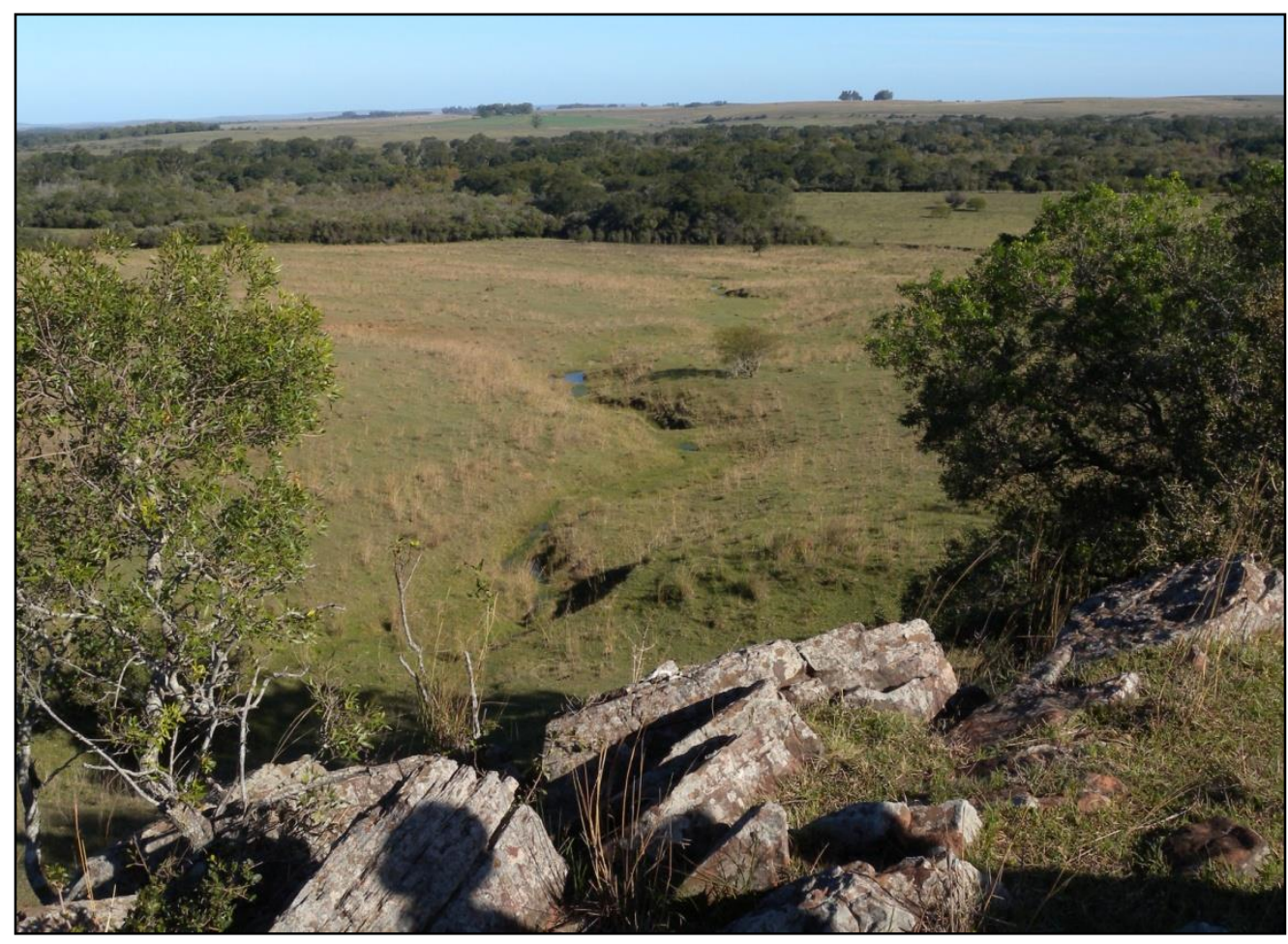

Fonte: Arquivo dos autores.

No plano de fundo da Figura 3 é possível observar a mata ciliar do rio lbirapuitã. Associada à margem deste curso d'agua ocorrem áreas planas com relevos mais rebaixados e declividades inferiores a $2 \%$. Formadas a partir de processos de acumulação, estas áreas estão localizadas próximo à margem dos cursos fluviais, ocorrendo principalmente na porção sul e sudestes da REBIO do Ibirapuitã.

Litologicamente a área é formada por rochas vulcânicas da Formação Serra Geral que recapeiam os topos das vertentes conferindo sustentação ao relevo suavemente ondulado resultando na formação de colinas (DE NARDIN, 2009). Estas rochas são constituídas por basalto, andesito basáltico e andesito incluídos na fácies Alegrete por Martins, Wildner e Hartmann (2011). Os derrames ocorreram inicialmente sobre as dunas que formavam o então ativo deserto Botucatu (WAICHEL; SCHERER; FRANK, 2008) preenchendo também as interdunas e marcando a paleotopografia na região. Na área de estudo as rochas vulcânicas afloram em duas condições distintas, sendo ambas importantes para controlar os processos de evolução das formas: a) em porções mais rebaixadas como junto à calha fluvial são responsáveis pelo controle do leito (leito rochoso); b) quando situadas em porções mais elevadas do relevo, são responsáveis por sustentar as formas. 
$\mathrm{Na}$ área de estudo as rochas sedimentares são representadas pelos arenitos eólicos da Formação Botucatu que constituem a base sob o qual ocorreram os derrames, por vezes ocorrendo porções onde se apresentam intertrápicos. Constituídos por quartzos de coloração laranjada, de tamanho fino a médio, com grãos bem arredondados e foscos, estas rochas geralmente apresentam textura homogênea e estratificação cruzada (SOARES, 2008).

Com diferentes condições de coesão diante da presença da sílica, é comum a ocorrência de veios de arenito em porções de contato com as rochas vulcânicas. Esta condição resulta em porções da rocha mais resistentes aos processos de intemperismo, por vezes aflorando matacões e lajes constituindo as formas de cornijas no terço superior da vertente. Apesar da relevância em termos de formas, estas condições não ocorrem em grande abrangência espacial. Neste sentido, as rochas sedimentares com maior representatividade espacial correspondem as porções de arenito friável que ocorrem em posição intercalada entre os afloramentos de rochas vulcânicas (Figura 4). Com maior suscetibilidade a processos erosivos, esta litologia apresenta maiores restrições quanto ao manejo. O mapa da Figura 4, apresenta a distribuição das litologias aflorantes e das principais feições do relevo presentes na REBIO do Ibirapuitã.

Figura 4 - Mapa ilustrando a distribuição espacial das litologias e feições relevantes.

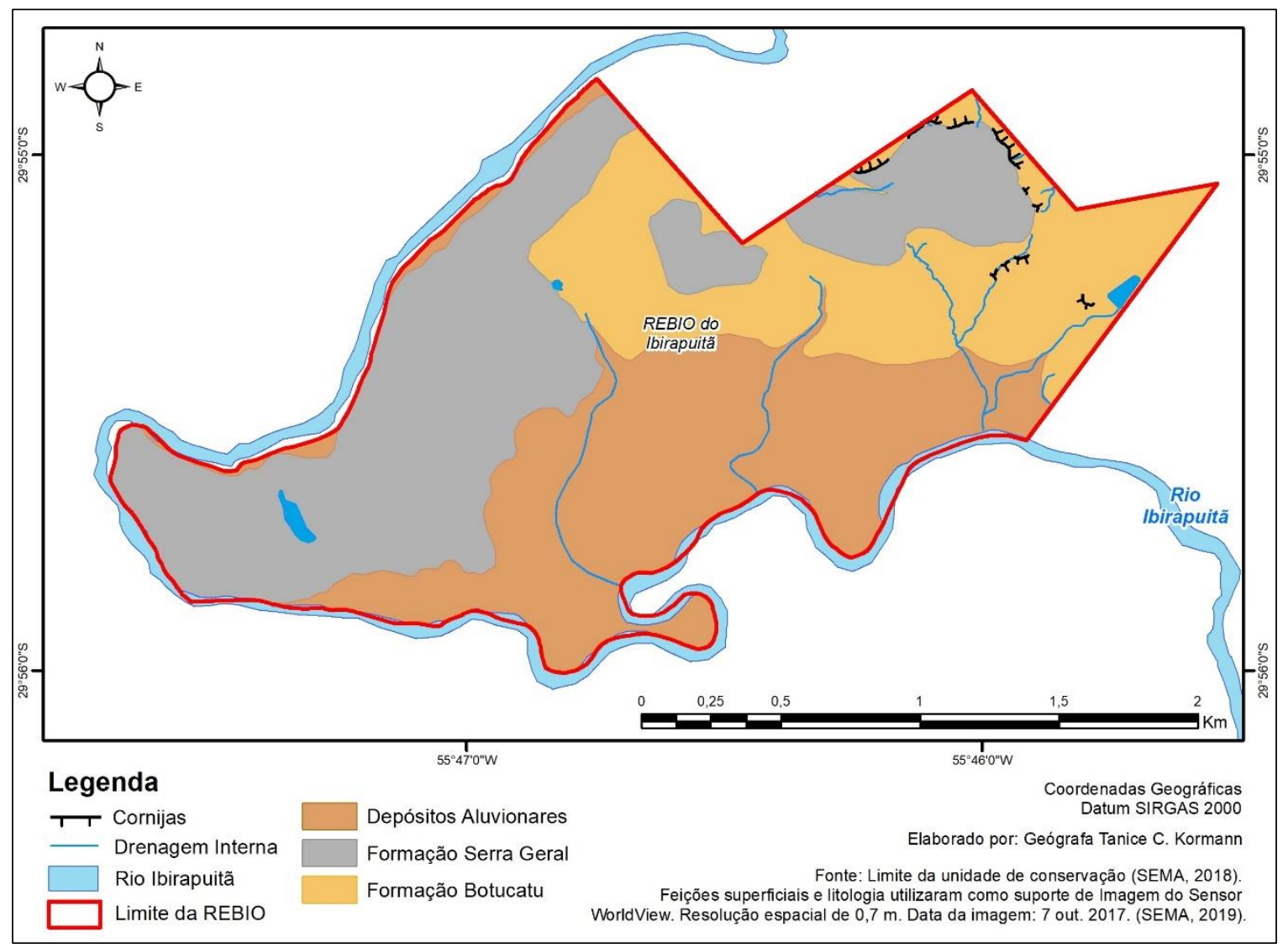

Fonte: Elaborado pelos autores.

Também conhecidos como terraços ou depósitos de calha da rede fluvial atual e subatual, os depósitos aluvionares correspondem a litologia mais recente, sujeita a dinamicidade em função dos pulsos de vazão do rio. Constituído por sedimentos de textura síltico-argilosa e arenosa inconsolidado, esta litologia resulta de processos de deposição fluvial ocasionados por sucessivos eventos de transbordamento do leito fluvial. Ocorrendo na parte sul - sudeste da REBIO do Ibirapuitã, esta litologia corresponde as extensas planícies aluviais formadas pela variação do leito fluvial. A Figura $5 \mathrm{~b}$ ilustra a formação de depósitos fluviais a partir do soterramento de meandros que sucessivamente foram abandonados pelo excesso de material depositado. 
Figura 5 - Ilustração dos processos da dinâmica fluvial do rio lbirapuitã. A) controle estrutural do leito fluvial junto ao limite oeste da REBIO. B) ocorrência de meandros em formação e meandros abandonados em porção de planície aluvial no centro sul da área.

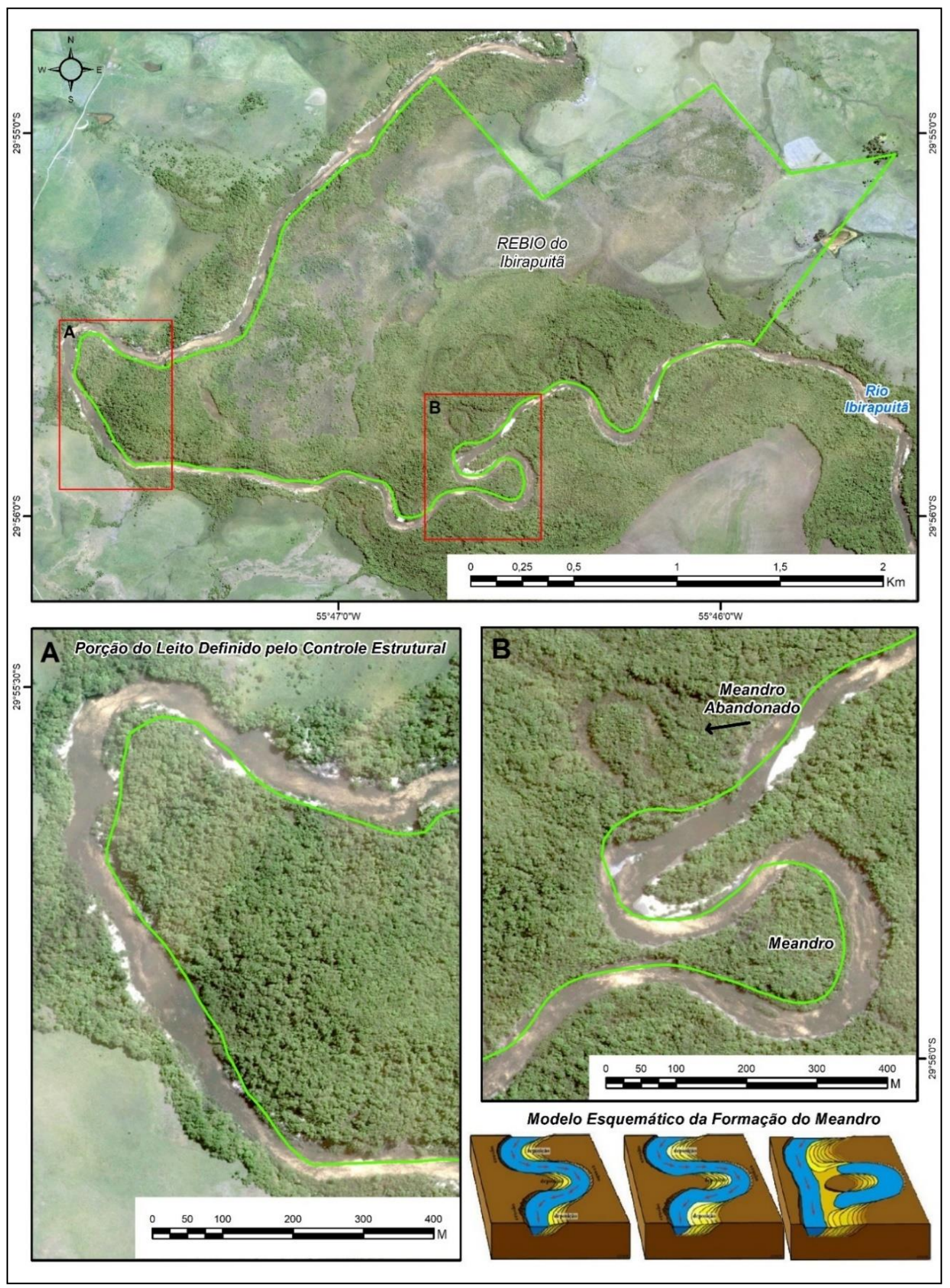

Fonte: Elaborado pelos autores. Modelo Esquemático de Formação do Meandro (DIAS, 2000). 
O leito fluvial tende a deslocar-se gradativamente na direção da margem côncava até que o meandro perde a ligação com o leito fluvial, resultando no meandro abandonado que constitui registro do longo processo natural de evolução do curso d'água. O termo "meandro" se refere a uma forma resultante de dinâmica de constante escavação e deposição do leito fluvial, resultado da dissipação de energia nos períodos de maiores vazões do canal gerando curvas sinuosas e largas (CHRISTOFOLETTI, 1981).

A Figura 5 ainda ilustra a ocorrência de margens rochosas onde afloraram as litologias vulcânicas que exercem um controle estrutural do leito fluvial, situação que ocorre na porção sudoeste da área protegida, conforme ilustrado na Figura 5a. Com cerca de 220 km de extensão, o rio lbirapuitã possui reduzida velocidade de fluxo e forte controle estrutural. Situada na porção de baixo curso da bacia hidrográfica, a REBIO do Ibirapuitã apresenta condições peculiares possibilitando a visualização de processos muito distintos espacialmente muito próximos. Na rede de drenagem interna da área de estudo predominam os canais intermitentes, principalmente de primeira e segunda ordem, geralmente nascendo na porção norte e desaguando na porção sul, sendo todos tributários do rio lbirapuitã.

A fim de facilitar a compreensão e sintetizar as informações relativas a geodiversidade da REBIO do Ibirapuitã é apresentado um perfil esquemático, em corte na direção SW-NE (Figura 6). Na parte inferior da figura constam fotografias ilustrando feições relevantes para a explicação dos processos anteriormente mencionados, além de descrições nos textos explicativos.

Figura 6 - Perfil esquemático ilustrando a litologia e relacionando com as feições superficiais.

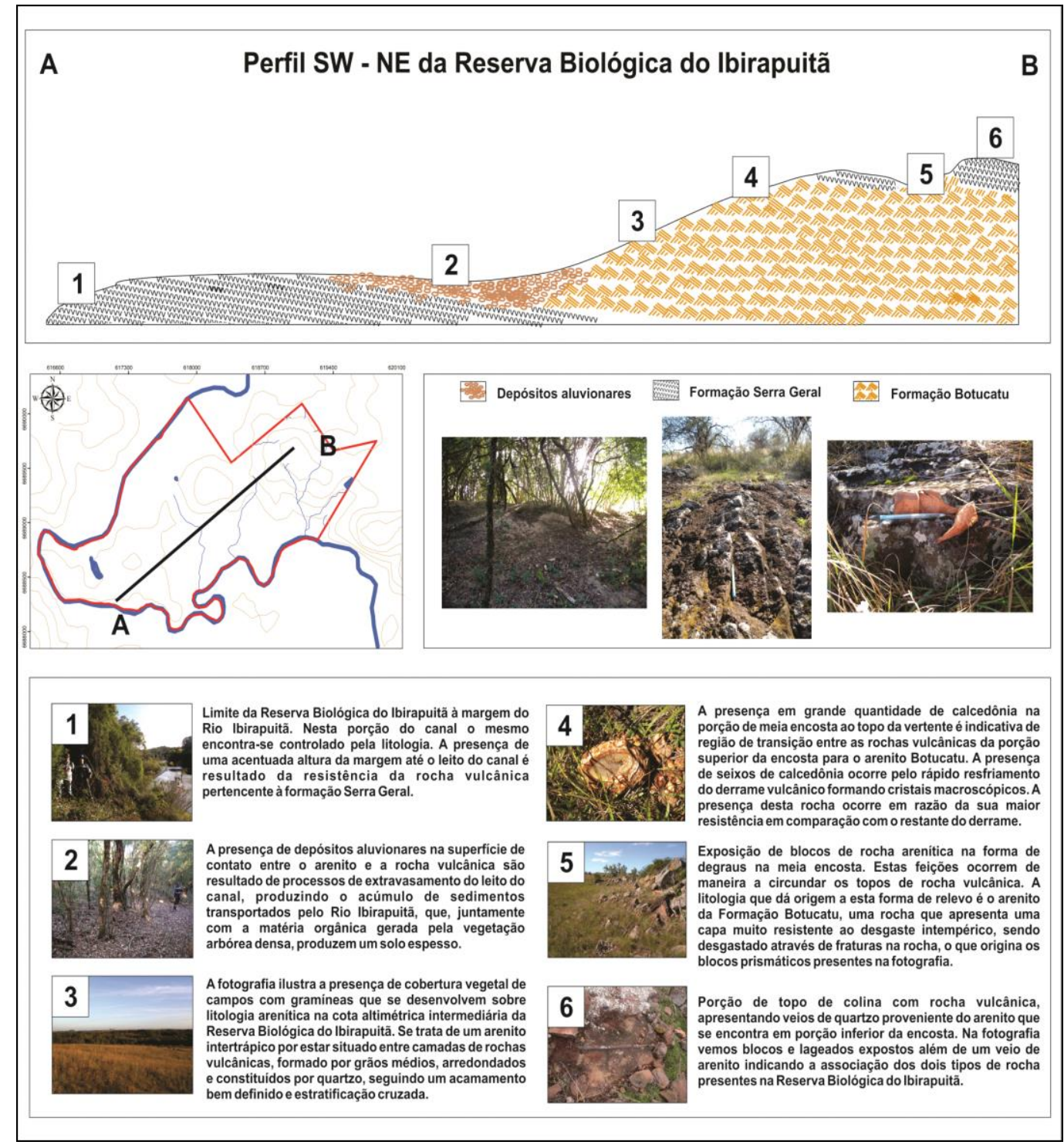

Fonte: KORMANN (2011). 
A partir da caracterização da geodiversidade da REBIO do Ibirapuitã é possível traçar paralelos com a distribuição espacial das distintas fisionomias vegetais presentes na área. Para tanto, a Figura 7 apresenta o resultado do mapeamento da cobertura vegetal da área protegida. Este mapa evidencia a relação da cobertura vegetal arbórea com a proximidade da drenagem de maior porte, permitindo, ainda, identificar o predomínio espacial da fisionomia vegetal bosque, que cobre cerca de $45 \%$ da área da REBIO do Ibirapuitã. Este predomínio reflete a significativa influência exercida pelo rio Ibirapuitã na cobertura vegetal local, sendo este o principal limite da área protegida.

Figura 7 - Mapa de distribuição das fisionomias vegetais da REBIO do Ibirapuitã.

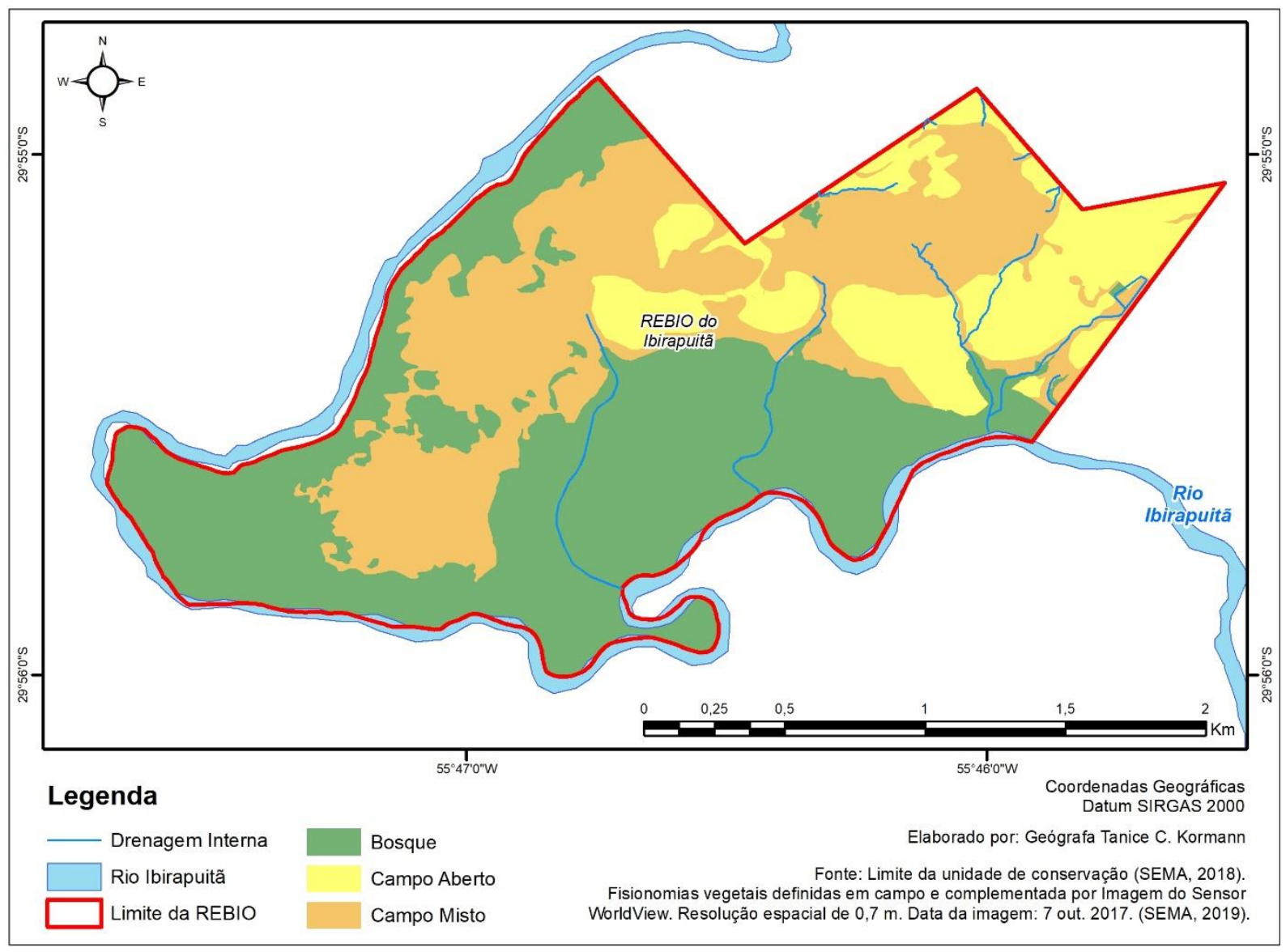

Fonte: Elaborado pelos autores.

A formação vegetal campo misto, também conhecida popularmente como campo sujo, corresponde a cerca de $35 \%$ da área de estudo. Ocorrendo nas porções mais elevadas do relevo (colinas), onde afloram as rochas vulcânicas, a formação campestre é intercalada por espécies arbóreas de menor porte, dentre as quais se destacam a cina-cina (Parkinsonia aculeata L.) e o espinilho (Vachellia caven (Mol.) Seigler \& Ebinger). Neste sentido, a REBIO do Ibirapuitã é representativa da fisionomia savanaparque com presença de espécies arbóreas de pequeno porte dentre as quais predominam o espinilho (Vachellia caven) e o algarrobo (Prosopis nigra (Griseb.) Hieron.). A Figura 8 ilustra o aspecto desta formação vegetal, denominada de campo misto, evidenciando o predomínio do espinilho, espécie da flora comum no Pampa.

A fisionomia vegetal que ocupa menos área é o campo aberto, popularmente conhecido como campo limpo, com ocorrência em aproximadamente $17 \%$ da área total da REBIO do Ibirapuitã. A ocorrência desta tipologia vegetal na porção centro leste da área indica mais do que uma correlação negativa com relação à rede de drenagem, mas principalmente uma correlação direta com o substrato rochoso da Formação Botucatu. Associado à ocorrência das porções desta litologia arenítica mais friáveis o solo é pouco desenvolvido sendo muito suscetível a processos erosivos. Em tais condições são ausentes as espécies arbóreas, havendo a presença exclusiva de espécies gramíneas. 
Figura 8 - Predomínio do espinilho (Vachellia caven), espécie arbórea/arbustiva que se destaca entre as gramíneas, correspondendo a formação vegetal campo misto.

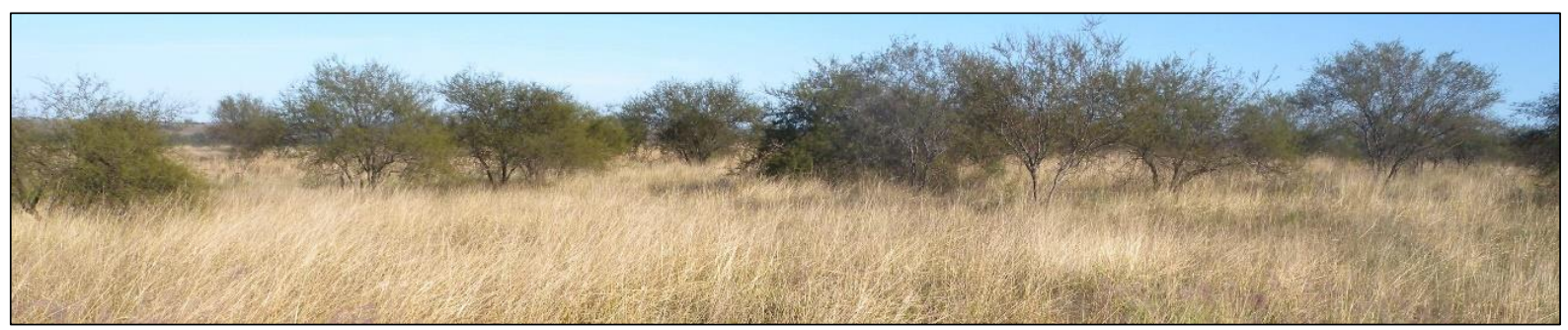

Fonte: Arquivo dos autores.

A Figura 9 ilustra o aspecto do campo aberto na estação de outono em oposição, ao fundo, à fisionomia bosque com espécies arbóreas de maior porte constituído densa mata ciliar do Rio Ibirapuitã.

Figura 9 - O primeiro plano ilustra a formação vegetal campo aberto e no plano de fundo a vegetação arbórea densa correspondente a fisionomia bosque.

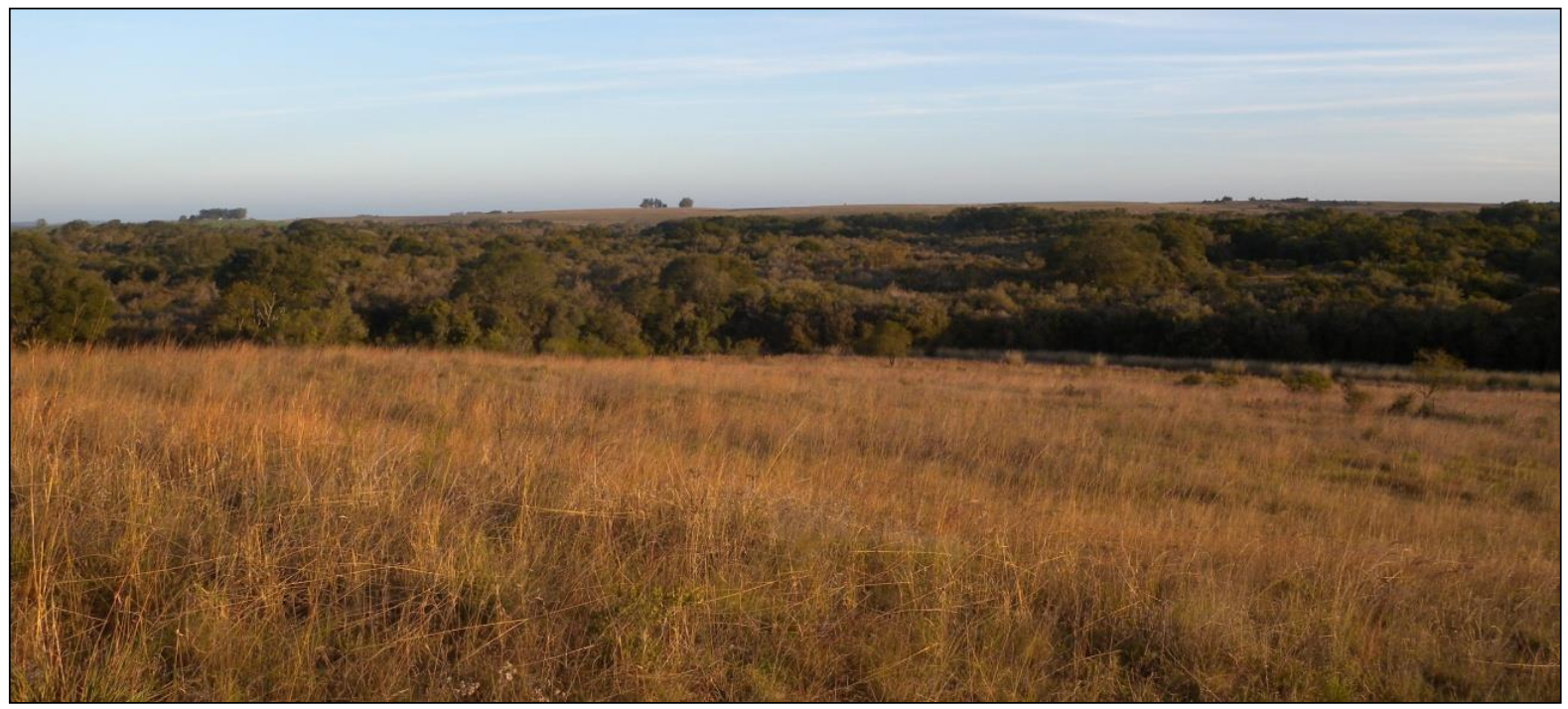

Fonte: Arquivo dos autores.

$\mathrm{Na}$ mata ciliar foram identificadas espécies como o angico-vermelho (Parapiptadenia rigida (Benth.) Brenan) e o açoita-cavalo (Luehea divaricata Mart. \& Zucc.). Se tratando de exemplares arbóreos de maior porte constituem bosque denso nas proximidades do rio lbirapuitã. $O$ desenvolvimento de vegetação arbórea densa e de grande porte indica condição de maior profundidade e fertilidade de solo, o que está relacionado a proximidade com a drenagem de maior porte no limite da UC.

A ocorrência de afloramentos rochosos constitui outro fator que atribui maior diversidade à fauna e flora da REBIO do Ibirapuitã. De difícil mapeamento em razão da escala, os afloramentos rochosos indicados no mapeamento são aqueles que apresentaram maior continuidade e linearidade, ou seja, aqueles associados a formação de cornijas e, portanto, afloramentos em rochas sedimentares. No entanto, fazse importante destacar que também ocorrem, em menor escala, afloramentos em rochas vulcânicas. Por meio da flora é possível fazer a distinção da ocorrência de afloramentos em rochas sedimentares para os afloramentos em rochas vulcânicas.

Afloramentos rochosos em substrato cristalino estão situados em porção de topo do relevo assumindo formas mais regulares e menos angulosas em função da maior resistência e da baixa permeabilidade, o que resulta na formação de depósitos de água nos períodos chuvosos. Nesta condição, verifica-se a ocorrência de liquens, musgos e cactáceas que recobrem quase completamente a rocha (Figura 10).

Enquanto os afloramentos em rochas sedimentares que estão associados a feições do tipo cornija, são associados a ocorrência da criúva (Agarista eucalyptoides (Cham. \& Schltdl.) G.Don) e do curupi 
(Sapium haematospermum Müll. Arg.) que podem ser consideradas espécies geoindicadoras (ALVES, 2008). No plano central da fotografia constante na Figura 11 consta a primeira das espécies mencionadas, evidenciando sua associação com as referidas feições superficiais.

Figura 10 - Ocorrência de musgos, liquens e cactáceas em porção de topo de relevo onde afloram rochas vulcânicas na porção norte da REBIO do Ibirapuitã.

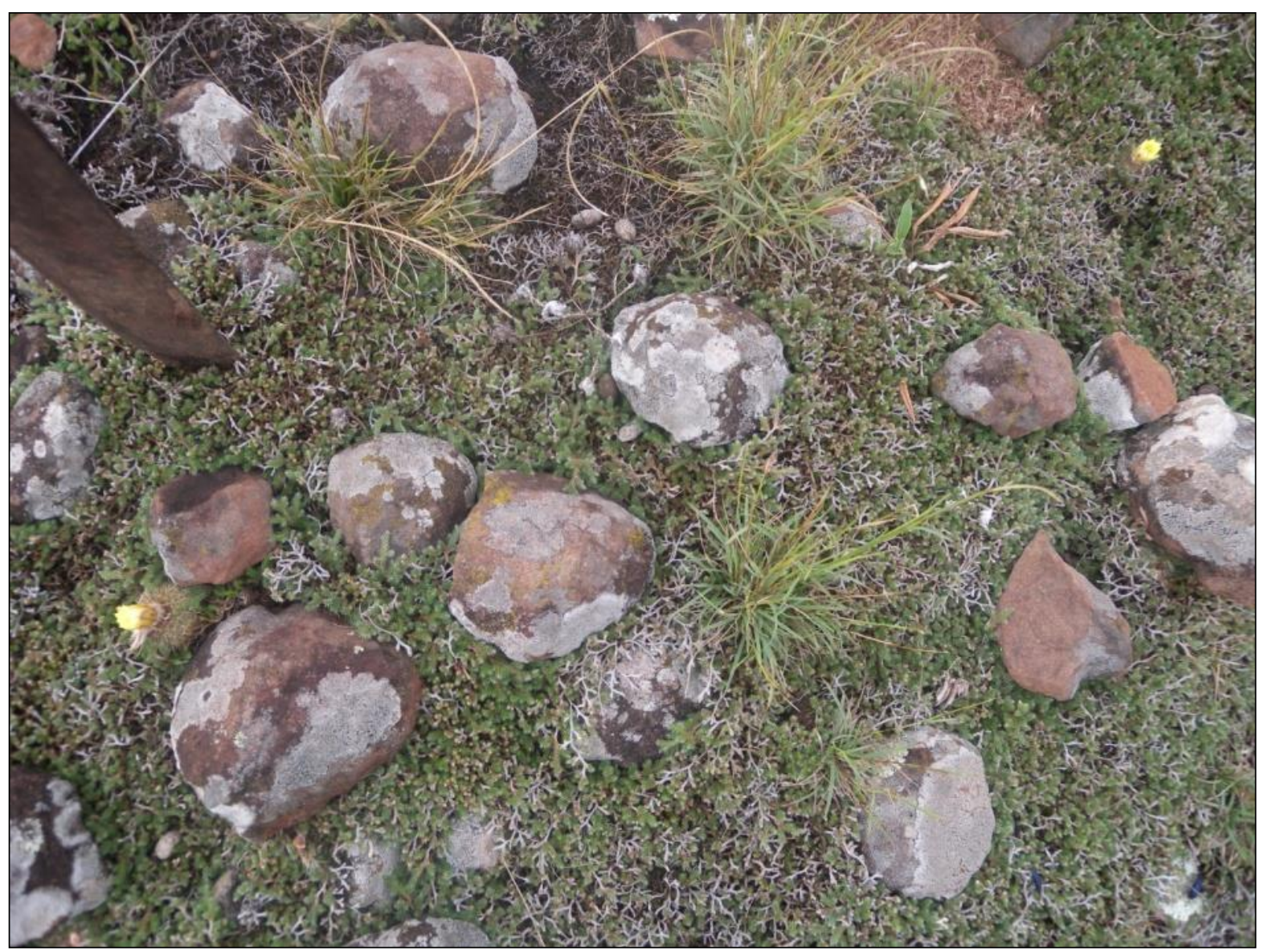

Fonte: Arquivo dos autores.

Figura 11 - Destaca-se a ocorrência de criúva (Agarista eucalyptoides) e sua associação com as cornijas em afloramentos rochosos areníticos.

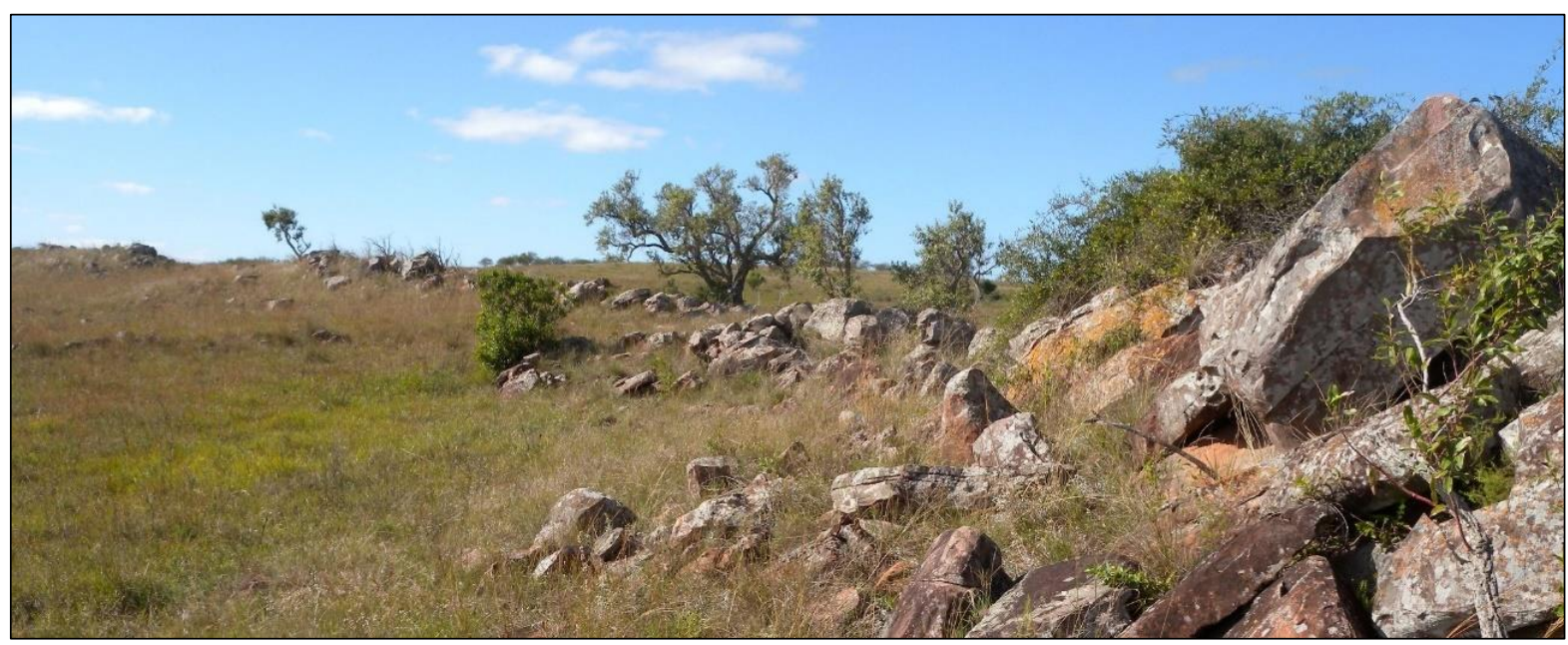

Fonte: Arquivo dos autores. 
Do mesmo modo que a distribuição da flora da REBIO do Ibirapuitã apresenta relação com a geodiversidade a fauna também permite o estabelecimento de correlações. Na REBIO do Ibirapuitã foi identificada uma nova espécie de mamífero endêmico: o tuco-tuco de colar (Ctenomys torquatus). Esta espécie se instala em locais de ocorrência de litologias sedimentares que permitem ao animal escavar sua toca (Figura 12). Apesar da necessidade de maiores estudos, há indícios de se tratar de um caso de endemismo (RORATTO, 2012).

Figura 12 - Fotografia do tuco-tuco de colar (Ctenomys torquatus).

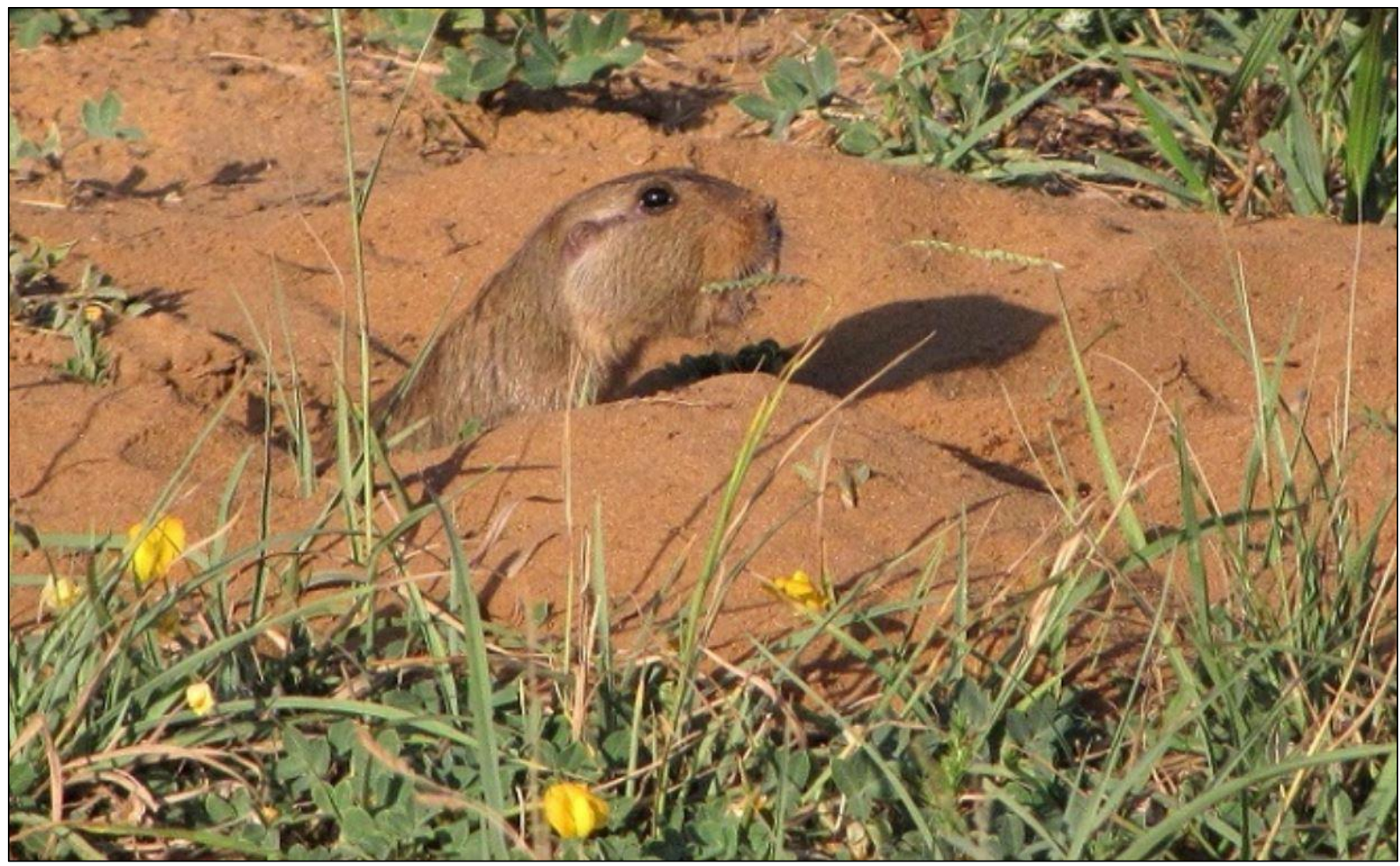

Fonte: (IANIRO, 2011).

Ainda no que se refere a diversidade da fauna na REBIO do Ibirapuitã, cabe mencionar que o local apresenta importância para a avifauna, sendo registradas em seu interior 122 espécies de aves (SEMA, 2001). Dentre as espécies de animais representativos do Pampa, destaca-se a ema (Rhea americana) que frequentemente é avistada nesta área protegida, indicando se tratar de importante local para a manutenção das condições ecológicas deste bioma.

\section{CONSIDERAÇÕES FINAIS}

Apesar da REBIO do Ibirapuitã ter sido criada com o enfoque de proteção da diversidade biológica, o trabalho evidenciou a importância de se considerar a geodiversidade para auxiliar na compreensão mais abrangente da biodiversidade da área. O presente trabalho buscou identificar os principais elementos que caracterizam a geodiversidade da REBIO do Ibirapuitã por meio do enfoque na geração de conhecimento em escala de detalhe local. Desta forma, a presente pesquisa permitiu reconhecer e dar evidência a processos e formas que são representativos da diversidade geológica e geomorfológica que caracterizam o bioma Pampa.

A litologia e a dinâmica da rede de drenagem foram os elementos de maior importância para estabelecer correlações com a distribuição da flora e fauna da REBIO do lbirapuitã. O trabalho evidenciou a ocorrência de padrão de distribuição florística relacionado a litologia e proximidade da rede de drenagem, fato que também se aplica a ocorrência de espécie da fauna. Desta forma, acreditase estar agregando conhecimento a respeito das formas e dos processos superficiais que ocorrem na 
área a fim de subsidiar a elaboração do Plano de Manejo, bem como auxiliar no cumprimento dos objetivos de proteção propostos desde a criação desta unidade de conservação.

Com uma proposta que enfatiza a interface, possibilitando aumentar a compreensão da geodiversidade e identificando interligações com a biodiversidade local, acredita-se estar contribuindo com a divulgação de informações de forma mais didática e acessível a comunidade em geral. Além disso, a pesquisa evidenciou que é por meio de um paradigma que valorize as interfaces e conexões entre a geodiversidade e a biodiversidade que se torna possível uma compreensão mais abrangente da natureza.

\section{AGRADECIMENTOS}

À SEMA pela autorização de pesquisa. À Fundação de Amparo à Pesquisa do Estado do Rio Grande do Sul (FAPERGS) pelo auxílio financeiro para saídas a campo, aos biólogos Fabiano da Silva Alves e João Carlos Pradella Dotto pelas contribuições na qualificação do presente trabalho.

\section{REFERÊNCIAS}

AB'SABER, A. N. Províncias geológicas e domínios morfoclimáticos no Brasil. Geomorfologia. São Paulo: USP, n. 20, 1970. p. 1 - 26.

ALVES, F. S. Estudo fitogeográficos na bacia hidrográfica do Arroio Lajeado Grande - Oeste do RS. 2008. 106 f. Dissertação (Mestrado em Geografia) - Universidade Federal de Santa Maria, Santa Maria, 2008.

BENSUSAN, N. Conservação da biodiversidade em áreas protegidas. Rio de Janeiro: Editora FGV, 2006.

BRASIL. Lei Federal no 9.985 de 18 de julho de 2000. "Regulamenta o art. 225, §1º, inciso I, II, III e VII da Constituição Federal, institui o Sistema Nacional de Unidades de Conservação da Natureza e dá outras providências". Presidência da República - Casa Civil, Brasília, DF, 18 jul. 2000. Disponível em: <http://www.planalto.gov.br/CCIVIL/Leis/L9985.htm>. Acesso em: 19 fev. 2011.

BRILHA, J. B. R. 2005. Património geológico, geoconservação: a conservação da natureza na sua vertente geológica. Braga, Portugal: Palimage, 2005. 190 p. Disponível em:

$<$ http://www.dct.uminho.pt/docentes/pdfs/ib livro.pdf>. Acesso em: 11 nov. 2019.

CARCAVILLA, L.; DURÁN, J.J.; Y LÓPEZ-MARTÍNEZ, J. Geodiversidad: concepto y relación con el patrimonio geológico. CONGRESO GEOLÓGICO DE ESPAÑA, 7, 2008, Las Palmas de Gran Canaria. Anais. Geo-Temas, v. 10, 2008. p. 1299-1303.

CHOMENKO, L.; BENCKE, G. A. (Orgs.) Nosso Pampa desconhecido. Porto Alegre: Fundação Zoobotânica do Rio Grande do Sul, 2016.

CHRISTOFOLETTI, A. Geomorfologia fluvial. São Paulo: Edgard Blucher. 1981.

CRISTO, S. S. V. Abordagem geográfica e análise do Patrimônio Geomorfológico em Unidades de Conservação da Natureza: aplicação na Estação Ecológica Serra Geral do Tocantins e área de entorno - Estados do Tocantins e Bahia. 2013. 245 f. Tese (Doutorado em Geografia) - Programa de Pós-Graduação em Geografia, Universidade Federal do Rio Grande do Sul - UFRGS, Porto Alegre, 2013.

CROFTS, R.; GORDON, J. E. Geoconservation in protected areas. Parks, v. 20, n. 2, p. 61-76, 2014. https://doi.org/10.2305/IUCN.CH.2014.PARKS-20-2.RC.en

DE NARDIN, D. Zoneamento Geoambiental no oeste do Rio Grande do Sul: um estudo em bacias hidrográficas. 2009. 203 f. Dissertação (Mestrado em Geografia) - Programa de Pós-Graduação em Geografia, Universidade Federal do Rio Grande do Sul- UFRGS, Porto Alegre, 2009. https://doi.org/10.1590/S1982-45132010000300006

DIAS, J. A. Cheias: Sistemas Fluviais. Geologia Ambiental. 2000. Universidade do Algarve - UALG. Disponível em: <http://w3.ualg.pt/ jdias/GEOLAMB/GA3 cheias/GA33 SistFluviais/SistFluviais.html>. Acesso em 19 jan. 2020. 
FLORA DO BRASIL. Herbário Virtual. Jardim Botânico do Rio de Janeiro. Disponível em: $<$ http://floradobrasil.jbri.gov.br/reflora/herbarioVirtual >. Acesso em: 11 set. 2020.

FONTANA, V.; REED, S. Mais degradado que o Cerrado e Amazônia, Pampa é o bioma menos protegido do país. 2019. Disponível em: <https://www.nationalgeographicbrasil.com/meioambiente/2019/10/degradacao-cerrado-amazonia-pampa-bioma-brasil-rio-grande-do-sulvegetacao?fbclid=IwAR2-n2Fy3JBycZ0s3K6KIK a DOGzvKEGJNaNNjLf1vv7sK3 xfJO8 TmJ0>. Acesso em: 31 jan. 2020.

IANIRO, J. L. EcoRegistros.org - Registros ecológicos da comunidade: (Ctenomys torquatus). 2011. Disponível em: <http://www.ecoregistros.org/site br/imagen.php?id=111756>. Acesso em: 31 jan. 2020.

IBGE - Instituto Brasileiro de Geografia e Estatística. Geologia. Mapas. Escala 1:250.000. Folha SH.21-X-C. Rio de Janeiro: IBGE, 2003a. Disponível em:

<http://downloads.ibge.gov.br/downloads geociencias.htm>. Acesso em: 14 abr. 2011.

Geomorfologia. Mapa. Escala 1:250.000. Folha SH.21-X-C. Rio de Janeiro: IBGE, 2003b. Disponível em: <http://downloads.ibge.gov.br/downloads geociencias.htm>. Acesso em: 14 abr. 2011.

Vegetação. Mapa. Escala 1:250.000. Folha SH.21-X-C. Formato shapefile. Rio de Janeiro: IBGE, 2003c. Disponível em: <http://downloads.ibge.gov.br/downloads geociencias.htm>. Acesso em: 14 abr. 2011.

KORMANN, T. C. Caracterização Ambiental do Meio Físico da Reserva Biológica do Ibirapuitã. 2011. 62 f. Trabalho de Conclusão de Curso (Bacharelado em Geografia) - Universidade Federal de Santa Maria, Santa Maria, 2011.

KUPLICK, T. M.; CAPOANE, V.; COSTA, L. F. F. O avanço da soja no Bioma Pampa. Boletim Geográfico do Rio Grande do Sul, Porto Alegre, v. 31, p. 83-100, jun. 2018. Disponível em: $<$ https://revistas.fee.tche.br/index.php/boletim-geografico-rs/article/view/4102> Acesso em: 26 fev. 2020.

MARCHIORI, J. N. C.; ALVES, F. S. O Inhanduvá (Prosopis affinis Spreng.) no Rio Grande do Sul. 1 - Embasamento fitogeográfico e pendências terminológicas. Balduinia, Santa Maria, v. 24, p. 01-11, 2010. Disponível em: <https://periodicos.ufsm.br/balduinia/article/view/14110> Acesso em: 11 set. 2020.

MARTINS, L. C.; WILDNER, W.; HARTMANN, L. A. Estratigrafia dos derrames da província vulcânica paraná na região oeste do Rio Grande do Sul, Brasil, com base em sondagem, perfilagem gamaespectrométrica e geologia de campo. Pesquisas em Geociências, v. 38, n. 1, p. 15-27, 2011. https://doi.org/10.22456/1807-9806.23833

REYNARD, E.; BRILHA, J. Geoheritage: Assessment, Protection and Management. Amsterdam: Elsevier, 2018. https://doi.org/10.1016/B978-0-12-809531-7.00008-3

RIO GRANDE DO SUL. Decreto Estadual no 24.622 de 10 de junho de 1976. "Cria a Reserva Biológica de Ibirapuitã, no Município de Alegrete". Assembleia Legislativa, Porto Alegre, RS, 10 jun. 1976. Disponível em:

$<$ http://www.al.rs.gov.br/legis/M010/M0100099.ASP?Hid Tipo=TEXTO\&Hid TodasNormas=32629\&h Texto=\&Hid IDNorma=32629 > . Acesso em: 26 out. 2019.

Decreto Estadual no 38.814 de 26 de agosto de 1998. "Regulamenta o Sistema Estadual de Unidades de Conservação - SEUC e dá outras providências". Assembleia Legislativa, Porto Alegre, RS, 26 ago. 1998. Disponível em:

$<$ http://www.al.rs.gov.br/legis/M010/M0100099.ASP?Hid Tipo=TEXTO\&Hid TodasNormas=6124\&hT exto=\&Hid IDNorma=6124>. Acesso em: 26 out. 2010.

RORATTO, P. A. Tuco-tucos do Pampa Rio-Grandense: a filogeografia de Ctenomys torquatus (Rodentia - Ctenomyidae) 2012. $180 \mathrm{f}$. Tese (Doutorado em Genética e Biologia Molecular) -

Programa de Pós-Graduação em Genética e Biologia Molecular, Universidade Federal do Rio Grande do Sul - UFRGS, Porto Alegre, 2012. 
SEMA - SECRETARIA DE MEIO AMBIENTE DO RIO GRANDE DO SUL. Subsídios para a elaboração do Plano de Manejo da Reserva Biológica de lbirapuitã. Porto Alegre: SEMA/Magna, 2001.

SEMA - SECRETARIA DE MEIO AMBIENTE E INFRAESTRUTURA DO RIO GRANDE DO SUL. Base cartográfica do Estado do Rio Grande do Sul. Escala 1:25.000. Formato shapefile. Porto Alegre: SEMA, 2018. Disponível em: <https://www.sema.rs.gov.br/cartografia >. Acesso em: 11 abr. 2019.

SEMA - SECRETARIA DE MEIO AMBIENTE E INFRAESTRUTURA DO RIO GRANDE DO SUL. Imagem de satélite. Sensor WorldView. Resolução espacial de 0,7 m. Resolução radiométrica de 8 bits. Data da imagem: 7 out. 2017. Porto Alegre: SEMA, 2019.

SILVA, J. X.; ZAIDAN, R. T. (Orgs.). Geoprocessamento \& análise ambiental: aplicações. Rio de Janeiro: Bertrand Brasil, 2004.

SOARES, A. P. Variabilidade espacial no sistema aqüífero Guarani: controles estratigráficos e estruturais. 2008. 196 f. Tese (Doutorado em Geociências) - Programa de Pós-Graduação em Geociências, Universidade Federal do Rio Grande do Sul - UFRGS, Porto Alegre, 2008.

WAICHEL, B. L.; SCHERER, C. M. S.; FRANK, H. T. Basaltic lava flows covering active aeolian dunes in the Paraná Basin in southern Brazil: Features and emplacement aspects. Journal of Volcanology and Geothermal Research, v. 171, n. 1-2, p. 59-72, 2008.

https://doi.org/10.1016/i.jvolgeores.2007.11.004

Recebido em: 02/04/2020

Aceito para publicação em: 15/09/2020 